\title{
A feeding association between Wilson's Storm-petrels Oceanites oceanicus (Kuhl, 1820) and Rough-toothed Dolphins Steno bredanensis (G. Cuvier in Lesson, 1828)
}

\author{
Fábio Olmos $^{1,3}$, Elsie Rotenberg ${ }^{2} \&$ Edelcio Muscat ${ }^{2}$ \\ ${ }^{1}$ Largo do Paissandú 100/4C, CEP 01034-010, São Paulo, SP, Brazil \\ ${ }^{2}$ Projeto Dacnis, Estrada do Rio Escuro 4954, CEP 11680-000, Ubatuba, SP, Brazil \\ ${ }^{3}$ Corresponding author:f-olmos@uol.com.br
}

OLMOS, F., ROTENBERG, E. \& MUSCAT, E. A feeding association between Wilson's Storm-petrels Oceanites oceanicus (Kuhl, 1820) and Rough-toothed Dolphins Steno bredanensis (G. Cuvier in Lesson, 1828). Biota Neotrop. 13(2): http://www.biotaneotropica.org.br/v13n2/en/abstract?shortcommunication+bn01013022013

Abstract: On 06 October 2012 a pod of Rough-toothed Dolphins Steno bredanensis (Delphinidae) was observed catching and tearing apart several Castin Leatherjacks Oligoplites saliens (Carangidae) near Montão de Trigo Island, northern coast of São Paulo, Brazil. The resulting floating masses of viscera attracted a feeding aggregation of 120-150 Wilson's Storm-petrels Oceanites oceanicus (Hydrobatidae), a transequatorial migrant passing through the area during October. This interspecific association has not been recorded before, although it could be expected given that $S$. bredanensis feeds on large fish and $O$. oceanicus is a known scavenger of kills made by cetaceans such as Killer Whales.

Keywords: behaviour, Brazil, feeding association, kleptoparasitism, Oceanites oceanicus, Steno bredanensis.

OLMOS, F., ROTENBERG, E. \& MUSCAT, E. Uma associação alimentar entre almas-de-mestre Oceanites oceanicus (Kuhl, 1820) e golfinhos-de-dentes-rugosos Steno bredanensis (G. Cuvier in Lesson, 1828). Biota Neotrop. 13(2): http://www.biotaneotropica.org.br/v13n2/pt/abstract?shortcommunication+ bn01013022013

Resumo: Em 06 de outubro de 2012 um grupo de golfinhos-de-dentes-rugosos Steno bredanensis (Delphinidae) foi observado capturando e despedaçando diversas guaiviras Oligoplites saliens (Carangidae) próximo à ilha Montão de Trigo, litoral norte de São Paulo. As massas de vísceras flutuantes atraíram uma agregação de 120-150 almas-de-mestre Oceanites oceanicus (Hydrobatidae), um migrante transequatorial que passa pela região em outubro. Esta associação interespecífica ainda não havia sido reportada, mas seria esperada, uma vez que $S$. bredanensis se alimenta de peixes de maior porte e $O$. oceanicus é atraído pelos restos de presas capturadas por cetáceos como orcas.

Palavras-chave: comportamento alimentar, Brasil, associação interespecifica, cleptoparasitismo, Oceanites oceanicus, Steno bredanensis. 


\section{Introduction}

Several seabird species are known to associate with foraging cetaceans to take opportunity of live prey disturbed and pushed closer to the surface (Monteiro-Filho 1992, Au \& Pitman 1986, Martin 1986, Clua \& Grosvalet 2001, Cremer et al. 2004, Vaughn et al. 2008) or remains that can be scavenged (Evans 1982, Hodges \& Woehler 1993, Pitman \& Durban 2010). Such associations may provide important food resources for seabirds (Evans 1982, Pierotti 1988, Shealer 2001), some species showing strong association to cetaceans (such as Procellaria parkinsoni, see Pitman \& Balance 1992).

Although the diets and feeding behaviours of coastal resident and locally migratory seabirds in Brazil are fairly well known (see Branco 2004), this kind of data for pelagic non-breeders such as most Procellariiformes is mostly limited to interactions with fisheries and birds incidentally killed by these activities (Olmos 1997, Colabuono \& Vooren 2006, Olmos \& Bugoni 2006, Bugoni et al. 2011), with only a few exceptions (Scherer et al. 2010). Opportunistic records of natural feeding events provide a glimpse on the ecology of those seabirds, and here we describe one such observation made near the coast of northern São Paulo, Brazil.

\section{Material and Methods}

The coastal shelf of the northern coast of São Paulo includes some of the best studied parts of the Brazilian coast (Rossi-Wongtschowski \& Madureira 2006, Pires-Vanin 2008). The study area is in a transition zone between the Argentine (temperate-subtropical) and the Brazilian (tropical) zoogeographic province (Briggs 1974), being under the influence of warm oligotrophic waters from the Brazil Current and cold nutrient-rich waters from the Falklands Current, being also influenced by cold and nutrient-rich water intrusions of the South Atlantic Central Water (SACW) over the shelf, and summer upwelling (Matsuura, 1986, Castro-Filho \& Miranda 1998).

The shelf has a gentle slope, the $50 \mathrm{~m}$ isobaths around $50 \mathrm{~km}$ from shore and the $100 \mathrm{~m}$ isobaths over $100 \mathrm{~km}$. In the area in which we carried out our observations, depths generally range from 8 to $40 \mathrm{~m}$, bottoms being mostly sandy with scattered rocky shoals near the islands dotting this part of the coast. Surface water temperatures range between $21-28^{\circ} \mathrm{C}$ during the summer and $19-23{ }^{\circ} \mathrm{C}$ during the winter, when salinity is also lower (Castro et al. 2008).

The observations reported here were made as part of the Expedições de Avistagem em Alcatrazes, a citizen science project promoted by the Tupinambás Ecological Station together with the Ilhabela and Barra do Una yacht clubs and the Instituto Oceanográfico da Universidade de São Paulo aiming to increase the knowledge of the local communities of seabirds and marine mammals by recording sightings along standard routes between the mainland and Alcatrazes island ( $\left.24^{\circ} 06^{\prime} \mathrm{S}, 45^{\circ} 42^{\prime} \mathrm{W}\right)$.

\section{Results and Discussion}

Observations were made on 06 October 2012 around $23^{\circ} 52$ 'S and $45^{\circ} 44^{\prime}$ ' $\mathrm{W}$ in waters $21.4 \mathrm{~m}$ deep, $4.3 \mathrm{~km}$ east of Montão de Trigo island and $10.8 \mathrm{~km}$ from the mainland. Despite a cold front blowing southern winds, sea conditions were calm but water visibility was poor, under five meters.

A few Wilson's Storm-petrels Oceanites oceanicus (Kuhl, 1820) flying west along the coastline were noticed soon after we left port at Barra do Una and headed to Alcatrazes, $38 \mathrm{~km}$ away, the first almost at the mouth of the Una river $\left(23^{\circ} 45^{\prime} \mathrm{S}\right.$ and $\left.45^{\circ} 45^{\prime} \mathrm{W}\right)$. At 09:05 we noticed a number of petrels west of our route towards Montão de Trigo and soon realised a small flock was feeding on the surface while several more birds flew around. As we approached we sighted a pod of at least 13 Rough-toothed Dolphins Steno bredanensis (G. Cuvier in Lesson, 1828) and it became clear the petrels were following the cetaceans.

As we drew closer, the dolphins would gather side by side on the surface some distance away from the boat, approach and follow alongside our slow-moving vessel or dive. It was clear the dolphins were fishing, the way some swam side by side (11 were photographed together) reminiscent of the fishing behaviour described by Pitman \& Stinchcomb (2002), but it was difficult to discern if the dolphins were hunting in a coordinated way.

Dolphins were seen to come to the surface holding fairly-sized fish at least $40 \mathrm{~cm}$ long a minimum of five times, a pair of such fish being identified from observations and photos (Figure 1) as Castin Leatherjacks Oligoplites saliens (Bloch, 1793), a common inshore schooling predatory Carangidae reaching $50 \mathrm{~cm}$ that has dorsal and anal spines that can inflict painful wounds (Carvalho Filho 1992).

Captured fish were carried along the surface for a while, sometimes towards the other dolphins moving slowly on the surface, perhaps for sharing. Fish were torn into pieces when the dolphins were submerged. Although this behaviour may have been influenced by our presence, we once observed violent splashing and one dolphin with the tail out of the water when two dolphins were either fighting for or tearing a fish apart together (or both). The leatherjacks were obviously too big to be eaten whole and breaking them could help the dolphins avoid wounds from the spines. As a result, floating viscera would pop out where the dolphins fed.

These attracted the immediate attention of the storm petrels. They would gather at the floating mass, up to 18 at a time, until it was totally consumed, sank or was taken by one of two juvenile Magnificent Frigatebirds Fregata magnificens also attending the feeding aggregation. The frigates were also seen to take food from storm-petrels twice. A lone juvenile Brown Booby Sula leucogaster flying around never attempted to catch the remains. Storm Petrels were seen patting on the surface while feeding, the usual behaviour displayed by this bird (Brooke 2004), and to dive, submerging completely in order to retrieve pieces of food.

Feeding on floating viscera was recorded seven times but is likely to be an underestimation of the number of fish actually taken since we arrived on the scene when the hunt was already on. Judging from the number of birds flying around, between 120 and 150 storm-petrels gathered around the dolphins, an estimate made difficult since the birds remained airborne, only briefly resting on the water.

We followed the dolphins slowly, sometimes holding our position to observe and take pictures, staying with the cetaceans until 09:46. At the end of our observations the dolphins closed ranks, with 11 swimming side by side away from the boat, still followed by some storm-petrels.

Steno bredanensis is a pantropical species (West et al. 2011) found along the Brazilian coast, with regular records along the coast of São Paulo (Martuscelli et al. 1996, Santos et al. 2010). This dolphin has a seemingly diverse diet (West et al. 2011) that includes large fish like $50 \mathrm{~cm}$-long remoras (Echeneidae, Wedekin et al. 2004) and 1.5 m-long Dolphinfish Coryphaena hippurus (Coryphaenidae, Pitman \& Stinchcomb 2002); the species has been suggested to be specifically adapted to handle such prey (Pitman \& Stinchcomb 2002), an affair that requires dismembering and results in scraps that may float into reach of attending seabirds.

Oceanites oceanicus is a transequatorial migrant that, in the Atlantic, nests in Antarctica, sub-antarctic islands such as South Georgia and southernmost South America. This petrel migrates to the north Atlantic up to $60^{\circ} \mathrm{N}$ for the austral winter, returning to its breeding grounds by October. There it feeds mostly on amphipods, 

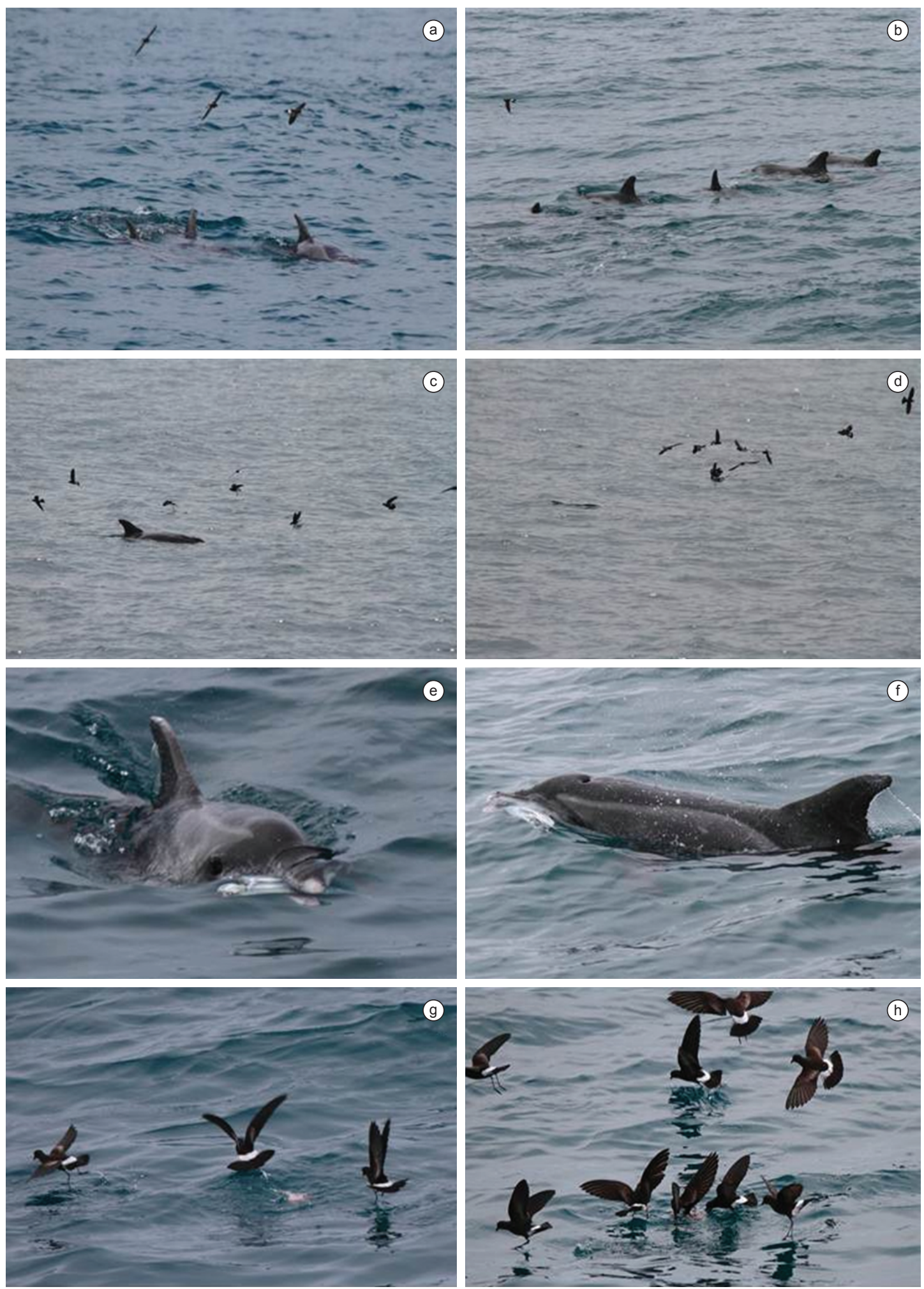

Figure 1. a-b) Rough-toothed Dolphins Steno bredanensis swimming side by side being followed by Wilson's Storm-petrels Oceanites oceanicus; c) a dolphin emerges as a mass of viscera pops to its right, attracting a storm-petrel; d) more storm-petrels flew to the mass as the dolphin submerges; e-f) dolphins carrying Castin Leatherjacks Oligoplites saliens; $\mathbf{g - h}$ ) storm-petrels feeding on scraps left by the dolphins.

krill and squid, with the occasional myctophid lantern fish or barnacle larvae (Brooke 2004). The diet elsewhere in the Atlantic is poorly known but includes plankton and scavenged items (Brooke 2004, Olmos 1997).
This storm-petrel is also an opportunist known to be readily attracted by slicks left by Killer Whales Orcinus spp. when dismembering prey like penguins, seals and whales (Hodges \& Woehler 1993, Pitman \& Durban 2010, 2011), also attending fishing 
boats to feed on discards like floating fish viscera, especially shark livers (Olmos 1997, Gandini \& Pon 2007, F. Olmos pers. obs.). Small numbers of $O$. oceanicus have also been observed to be attracted by feeding pods of Atlantic Spotted Dolphins Stenella frontalis off the shelf of southern São Paulo (Scherer et al. 2010) but the prey species was not identified. In this case the small number of storm-petrels (only two out of over 70 seabirds) suggests either reduced numbers in the area or poor feeding opportunities because the prey was too small for the dolphins to leave sizable scraps.

A known scavenger of cetacean kills being attracted by the remains of prey left by dolphins catching large fish is to be expected, although the number of birds we observed and their proximity to shore were both remarkable. Since $O$. oceanicus is expected to fly by the Brazilian coast at that time of the year on the way to its nesting grounds - a voyage where they cross large expanses of ocean with poor feeding opportunities for a plankton-eater -, the fortuitous encounter of foraging dolphins may have provided a welcome feeding opportunity for the migrant birds.

\section{Acknowledgements}

The observations reported here were recorded during the III Expedição de Avistagem em Alcatrazes. Our thanks to Julio Cardoso for inviting us to take part in these expeditions and the great time aboard the Ballerina, to Kelen Leite and the staff of the Estação Ecológica Tupinambás for making this project possible and to Ivan Sazima and Fernando Gibran for confirming the identity of the photographed fish.

\section{References}

AU, D.W.K. \& PITMAN, R.L. 1986. Seabird associations with dolphins and tuna in the Eastern Tropical Pacific. Condor 88:304-317. http://dx.doi. org $/ 10.2307 / 1368877$

BRANCO, J.O. 2004. Aves marinhas e insulares brasileiras: bioecologia e conservação. Editora UNIVALI, Itajaí.

BRIGGS, J.C. 1974. Marine zoogeography. McGraw-Hill, New York.

BROOKE, M. 2004. Albatrosses and petrels of the world. Oxford University Press, Oxford.

BUGONI, L., GRIFFITHS, K. \& FURNESS, R.W. 2011. Sex-biased incidental mortality of albatrosses and petrels in longline fisheries: differential distributions at sea or differential access to baits mediated by sexual size dimorphism? J. Ornithol. 152:261-268. http://dx.doi.org/10.1007/ s10336-010-0577-x

CARVAlHO FILHO, A. 1992. Peixes da costa brasileira. Editora Marca D’Água, São Paulo.

CASTRO, B.M., MIRANDA, L.B., SILVA, L.S., FONTES, R.F.C., PEREIRA, A.F. \& COELHO, A.L. 2008. Processos físicos: hidrografia, circulação e transporte. In Oceanografia de um ecossistema subtropical (A.M.S. Pires-Vanin, org). EDUSP, São Paulo, p.59-122.

CASTRO-FILHO, B.M. \& MIRANDA, L.B. 1998. Physical oceanography of the western Atlantic continental shelf between $4^{\circ} \mathrm{N}$ and $34^{\circ} \mathrm{S}$. In The Global Coastal Oceans: Processes and Methods (Brink, K. H. \& A. R. Robinson, eds.). John Wiley \& Sons, Inc., New York, p.209-251, v.10.

CLUA, E. \& GROSVALET, F. 2001. Mixed-species feeding aggregations of dolphins, large tunas and seabirds in the Azores. Aquat. Living Resourc. 14:11-18. http://dx.doi.org/10.1016/S0990-7440(00)01097-4

COLABUONO, F.I. \& VOOREN, C.M. 2006. Hábitos alimentares de alguns albatrozes e petréis na região Sul do Brazil. In Aves oceânicas e suas interações com a pesca na Região Sudeste-Sul do Brasil (T. S. Neves, L. Bugoni \& C. L. D. B. Rossi-Wngtschowski, orgs.). Instituto Oceanográfico-USP, São Paulo, p.83-102.

CREMER, M.J., LOPES, P.C.S. \& PIRES, J.S.R. 2004. Interações entre aves marinhas e Sotalia guianensis (P. J. Van Bénédén, 1864) na Baía da Babitonga, sul do Brasil. Rev. Bras. Zool. 6:103-114.
EVANS, P.G.H. 1982. Associations between seabirds and cetaceans: a review. Mamm. Rev. 12:187-206. http://dx.doi.org/10.1111/j.1365-2907.1982. tb00015.x

GANDINI, P.A. \& PON, J.P.S. 2007. Seabird assemblages attending longline vessels in the Argentinean economic exclusive zone. Ornitologia Neotropical. 18: 553-561.

HODGES, C.L. \& WOEHLER, E.J. 1993. Associations between seabirds and cetaceans in the Australian sector of the southern Indian Ocean. Mar. Ornithol. 22:205-212.

MARTIN, A. R. 1986. Feeding association between dolphins and shearwaters around the Azores Islands. Can. J. Zool. 64:1372-1374. http://dx.doi. org/10.1139/z86-205

MARTUSCELLI, P., OLMOS, F., SILVA e SILVA, R., MAZARELA, I.P, PINO, F.V., RADUAN, E. N., MILANELO, M. \& PAIVA, R. 1996. Cetaceans of São Paulo, southeastern Brazil. Mammalia 60(1):125-139. http://dx.doi.org/10.1515/mamm.1996.60.1.125

MATSUURA, Y. 1986. Contribuição ao estudo da estrutura oceanográfica da região sudeste entre Cabo Frio (RJ) e Cabo de Santa Marta Grande (SC). Ciênc. Cul. 38:1439-1450.

MONTEIRO-FILHO, E. L. A. 1992. Feeding associations between dolphins and seabirds. Rev. Bras. Zool. 9:29-37. http://dx.doi.org/10.1590/S010181751992000100005

OLMOS, F. 1997. Seabird flocks attending bottom long-line fishing off southeastern Brazil. Ibis 139:685-691. http://dx.doi.org/10.1111/j.1474919X.1997.tb04692.x

OLMOS, F. \& BUGONI, L. 2006. Agregações de aves marinhas associadas à pesca de espinhel-de-fundo na região Sudeste-Sul do Brasil. In Aves oceânicas e suas interações com a pesca na Região Sudeste-Sul do Brasil (T. S. Neves, L. Bugoni \& C. L. D. B. Rossi-Wngtschowski, orgs.). Instituto Oceanográfico-USP, São Paulo, p.69-81.

PIEROTTI, R. 1988. Associations between marine birds and mammals in the northwest Atlantic ocean. In Seabirds and other marine vertebrates: competition, predation and other interactions (J. Burger, ed.). Columbia University Press, New York, p.31-58.

PIRES-VANIN, A.M.S. 2008. Oceanografia de um ecossistema subtropical. EdUSP, São Paulo.

PITMAN, R.L. \& STINCHCOMB, C. 2002. Rough-Toothed Dolphins (Steno bredanensis) as predators of Mahimahi (Coryphaena hippurus). Pac. Sci. 56(4):447-450. http://dx.doi.org/10.1353/psc.2002.0043

PITMAN, R.L. \& DURBAN, J.W. 2010. Killer whale predation on penguins in Antarctica. Polar Biol. 33:1589-1594. http://dx.doi.org/10.1007/ s00300-010-0853-5

PITMAN, R.L. \& DURBAN, J.W. 2011. Cooperative hunting behavior, prey selectivity and prey handling by pack ice killer whales (Orcinus orca), type B, in Antarctic Peninsula waters. Mar. Mamm. Sci. 28:16-36. http:// dx.doi.org/10.1111/j.1748-7692.2010.00453.x

PITMAN, R.L. \& BALANCE, L.T. 1992. Parkinson's Petrel Distribution and Foraging Ecology in the Eastern Pacific: Aspects of an Exclusive Feeding Relationship with Dolphins. Condor 94:825-835. http://dx.doi. org $/ 10.2307 / 1369280$

ROSSI-WONGTSCHOWSKI, C.L.D.B. \& MADUREIRA, L.S.P. 2006. O ambiente oceanográfico da plataforma continental e do talude na região sudeste-sul do Brasil. EdUSP, São Paulo.

SANTOS, M.C.O., SICILIANO, S., VICENTE, A.F.C., ALVARENGA, F.S., ZAMPIROLLI, E., SOUZA, S.P. \& MARANHO, A. 2010. Cetacean records along São Paulo state coast, southeastern Brazil. Braz. J. Oceanogr. 58:123-142. http://dx.doi.org/10.1590/S167987592010000200004

SCHERER, A.L., PETERSEN, E.S., SCHUH, M.H., CRISTOFOLI, S.I.,TAVARES, C.L.M., DUARTE, A., PETRY, M.V. \& SANDER, M. 2010. Interação entre aves marinhas (Procellariiformes) e golfinhospintados-do-atlântico Stenella frontalis (Cetacea: Delphinidae) em águas oceânicas do sudeste do Brasil. Rev. Bras. Ornitol. 18:234-236. 
SHEALER, D.A. 2001. Foraging behavior and food of seabirds. In Biology of marine birds (E.A. Schreiber \& J. Burger, eds). CRC Press, Boca Raton, London, New York, Washington, p.137-177.

VAUGHN, R.L., WÜRSIG, B., SHELTON, D.S., TIMM, L.L. \& WATSON, L.A. (2008). Dusky dolphins influence prey accessibility for seabirds in Admiralty Bay, New Zealand. J. Mammal. 89:1051-1058. http://dx.doi. org/10.1644/07-MAMM-A-145.1
WEDEKIN, L.L., FREITAS, A., ENGEL, M.H. \& SAZIMA, I. 2004. RoughToothed Dolphins (Steno bredanensis) catch diskfishes while interacting with Humpback Whales (Megaptera novaeangliae) off Abrolhos Bank breeding ground, Southwest Atlantic. Aquat. Mamm. 30:327-329. http:// dx.doi.org/10.1578/AM.30.2.2004.327

WEST, K.L., MEAD, J.G. \& WHITE, W. 2011. Steno bredanensis (Cetacea: Delphinidae). Mamm. Species. 43:177-189. http://dx.doi. $\operatorname{org} / 10.1644 / 886.1$

Received 11/05/2010

Revised 02/19/2013

Accepted 04/19/2013 